\title{
SORTING OUT MODERN CONSTITUTIONAL PROVISIONS ON EMERGENCY. A TAXONOMIC FRAMEWORK.*
}

\section{Patricia Mindus}

The effort to link emergencies and constitutional norms has been an issue for political and legal scholarship ever since Charondas from Catania intended to ban modifications of the constitution through predetermined provisions. To make the point, Western political tradition coined a whole horde of mots faits: Salus populi suprema lex esto (let the good of the people be the supreme law), ad impossibilia nemo tenetur (no one is obliged to do the impossible), necessitas non habet legem (necessity knows no law), inter arma silent leges (in times of arms, the laws fall mute), down to the crystal-clear Videant consules, ne quid detrimenti capiat res publica (let the consuls see to it that the state suffer no harm).

The idea that necessity breaks law - which is a Swedish saying and judge-induced doctrine from the $14^{\text {th }}$ century - is just as cumbersome as it is pervasive in our legal culture. The saying was made fashionable by the German legal doctrine from the early $20^{\text {th }}$ century, its most elaborate formulation being Josef Kohler's Not kennt kein Gebot from 1915 (see also Bluntschli 1857, 109; Jellinek 1887, 367). It is worth recalling that Germany justified its invasion of Belgium on the basis of this doctrine.

Nevertheless, the very notion of "constitutional emergency" needs to be illustrated in proper detail, unless we want to settle for a some- 
what abstract and vague level of discussion as the default position. I therefore suggest a detailed analysis and an empirical investigation into its various modes of utilization. The empirical data is constituted by selected cases of modern emergency rules, constitutional in the main, with special reference to Sweden. This choice depends on the fact that accounts on emergency rule relating to this particular case are extremely scarce and incomplete in nature. ${ }^{1}$ Moreover, the choice depends on the current debates on these issues: Sweden has, in recent years, had extensive parliamentary debates concerning a revision of the constitution, a revision which may include the allocation of the main responsibility for managing the use of force in situations of war, and perhaps other forms of crisis, to the government and not to the parliament. ${ }^{2}$ Generally speaking, nödrätt is inspired by the ideal to preferably avoid or to minimize as much as possible any deviation from the path of constitutionalism. It has been stressed over again that Sweden is supposed to have a working Rechtsstaat even under extraordinary circumstances. We will look at how the constitution and the reform proposals live up to this ideal.

Aware of the fact that these emergency rules are interesting only within the framework of constitutional government, since tyrants and absolute sovereigns already enjoy absolute powers, the purpose is to suggest ways to discriminate between provisions that respect more or less the rule of law. This implies that Carl Schmitt's "sovereign dictatorship" is not the focus, but rather those forms of provisions that shun setting aside the constitutional arrangement (Dyzenhaus 1997, 1998). This kind of investigation is interesting in so far as it hinges on the problem of balancing two fundamental principles of constitutional government: Our right to be safe and our right to be free, where the maximizing of one of the two does not need to be its optimization. A fact to keep in mind is that many constitutional theorists reach for their pistols at the mere thought of derogating from the constitution. This understandable reaction ought perhaps to be nuanced and hopefully this taxonomic framework and the discussion of some cases can be a step towards grasping (and arranging) constitutional emergency rules in a more sophisticated way, enabling us to refine our ability to measure their quality.

In order to start drawing distinctions, we need to look at the degree of concentration of power. In fact, separation of powers is still today the archetypal tool we use to avoid emergency spilling over 


\section{PATRICIA MINDUS}

into tyranny. Political science and constitutional law usually examine exactly how concentrated emergency power is in a given context. Building on such inquiries, I shall sketch the basic lines of a theoretical framework, adding one simple criterion: Time, i.e. the chronological sequence that events inevitably follow. I would hereby like to contribute to furthering a more ordinate assessment and critical discussion.

Some of the constitutional emergency rules we find in modern law will thus be examined through the suggested framework. It will enable us to identify different levels and kinds of problems that are currently being indiscriminately mingled into the "constitutional emergency" discourse. I will illustrate the different categories or types of issues involved by setting them in a time sequence (before, during and after) against the backdrop of examples that I find particularly telling with regard to how a determinate constitution has found a way to deal with a specific issue. No constitutional provision, as far as I can see, satisfyingly deals with all issues. It is easy to understand why: Constitutions are historical artifacts, evolving over time, in different political, social and economic conditions. It is not surprising that a country feels particularly vulnerable to a kind of phenomenon to which another shows indifference.

Yet, an unavoidable premise is that I am interested in emergencyrelated norms closely connected to the constitution, not just any rule concerned with emergencies. Therefore, this study deals with cases that presuppose exceptional circumstances of "urgency and necessity" involving so-called emergency powers (i.e. derogatory provisions and power-attributing norms) that refer to the constitution as being the fundamental structure of a polity. A similar working definition, applying to Scandinavian constitutional doctrine, holds Konstitusjonell nødrett to be «a right to perform actions during extraordinary circumstances that contrast with constitutional rules but are in conformity with the principles of the constitution in order to secure important interests» (Castberg 1953, 4).

One difficulty that arises depends on the fact that we tend to use the same noun for indicating different things: The state of siege, for example, indicates both the emergency - say, a military siege, but also an insurrection or a war - and the institutional arrangement or legal provision that has been created in response to such phenomena (like for instance l'état de siège in the second French republic). This means that 
we often use the same word to indicate both the emergency and the way we deal with it.

Another major difficulty is to define the area of constitutional emergency. Emergency rules go far beyond the kind of provisions concerned with "constitutional dictatorship." They cover a complex set of situations, belonging to different legal fields, which would probably require an overall systematization that we lack today. Besides the classical institutions of international, constitutional and administrative law - such as state of siege, martial law, general mobilization, urgency decrees, armed bands, courts-martial, etc. - we find self-defense and state of necessity in criminal law, invalidity of contracts signed under threat in private law, precautionary measures in procedural law, down to emergency regulations in hospitals and traffic regulations for emergency vehicles. This means that different emergency-related norms are scattered throughout the legal system. In some legal traditions, such as the Nordic, where emergency refers to nödrätt/nødret(t), it is fairly difficult to tell the difference between, so-called ordinary emergency-rules and constitutional emergency rules (Benediktsson 1966; Lauta 2008).

Nödrätt - i.e. Emergency Law, Notrecht, droit de nécessité - includes norms in which appeal is made to necessity in diverse sectors of the law (Blomkvist 1972). In other words, there is no lexical distinction in the noun itself between emergency laws on a constitutional level and, say, self-defense in criminal law (Johansson 1985, 5). For instance, according to Swedish law, self-defense in criminal law (nödvärn) is grounded on "nödrätt" since the latter constitutes one of the general objective grounds for the principle of non-liability (See chapter 24 in the Swedish penal code Om nödvärn och annan nödhandling, especially $\S 4)$. Moreover, nödrätt is connected to collective self-defense as stated by the art. 51 in the UN Charter; a point that has also been stressed in the recent Swedish debates on the constitutional reform of emergency provisions (SOU 2008:125, 519). This umbrella notion of emergency has brought scholars to conclude that «if a minister - or even the entire government - ordered so-called bugging [i.e. illegal secret wire tapping] in what was held to be a situation of necessity, the eventual non-liability will first and foremost derive from the article on self-defense in the Criminal Code» (Jermsten 1992, 68). 


\section{PATRICIA MINDUS}

\section{What situations qualify for emergencies?}

In chronological sequence, the first problem that emerges with a crisis is to determine whether it actually is an emergency. What events can plausibly qualify for an "emergency"? Which features should these events have in order to justify the suspension of normalcy? In other words, the primary issue is to:

(a) Define emergency situations or action-classes (e.g. war, invasion, insurgency, natural disasters, famine, economic depression or recession...).

(b) Specify the features causing these situations to fit into the emergency category. Such features may include urgency and necessity, for instance. It may be debated as to whether they should include reasonable suspicion. (c) Determine whether the situation at hand actually meets the criteria.

Once we have an emergency, our second step will be to arrange for that emergency to be recognized. An unrecognized emergency, from this standpoint, is simply not a constitutional emergency. Which subjects and/or institutions are supposed to judge if the situation at hand, or the events we are facing, actually qualify for an emergency?

Even though legal and political scholars have inquired much on the topic of constitutional dictatorship, it is still safe to say that comparatively little attention has been paid to the nature of the threat. Unsurprisingly, this depends on the fact that threats may arise in very different ways and be of varying nature and intensity, thus making the task of the constitutional legislator highly unpleasant. Emblematically, Hamilton, in paper 23 of the Federalist Papers, held it to be impossible to foresee or define the extension and the variety of the needs of the nation, or the corresponding extension and variety of the means necessary to satisfy them. Lawyers often lament the risk of an over-detailed illustration of the matter.

It is, however, a little surprising to notice the lack of reflection that has become the standard response to Hamilton's comments. In particular, it is astonishing to see how extremely long-lived the doctrine of the double nature of emergencies is, that is the idea that threats may come from inside or outside the polity. Clearly, this twofold theory of the origin of emergencies is homage to the hermeneutics of sovereignty, but it leads to rather uncomfortable conclusions, for instance, that epidemics necessarily have a hexogen nature - boldly at odds with the 


\section{SORTING OUT MODERN CONSTITUTIONAL...}

basic teachings on endogenous virology taught at ordinary medical school! Moreover, globalization's blurring of borderlines, along with its transnational dimensions (e.g. the Internet) are destined to make the inside/outside explanation inadequate for grasping the great variety of causes behind real emergencies. Add to this the fact that there is a certain trend towards the rhetorical use of central notions in the vocabulary of emergencies, such as "war" (war on poverty, on terror, on drugs etc.), making the dual nature thesis appears increasingly untimely.

The theory of the dual nature of emergencies is, nonetheless, wellrooted in history: Emperor Claudio's Oratio Lugdunensis (I, 28) claimed that what ought to be feared are «terrible wars and severe agitation in the city.» For that reason the Roman dictator was nominated either for solving military issues (dictatura rei gerundae) or for suppressing insurgency (dictatura seditionis sedandae et rei gerundae causa). These two categories of events also appear, for instance, in the U.S. Constitution, where a situation qualifies for the state of emergency if we are witnessing «rebellion or invasion.»

The Swedish case is no exception: Because the 1772 Constitution gave the King the possibility to «take the measures and steps in conformity with the security of the reign and the subjects' pious agreement» - basically, the blank check of absolutism - the 1809 constitution, in reaction, dealt only with the state of war. But Sweden was not directly involved in war from 1814 onwards. The constitutional provisions were never tested. Today, emergency (nödrätt) is regulated by chapter 13 in the 1974 Constitution ${ }^{3}$ adopted after a lengthy drafting process that started with the constitutional committee appointed in 1954 to modernize the 1809 -form of state. Following the 1963 proposal (SOU 1963:16, 17 \& 18) of the Committee (Författningsutredningen) that included, in chapter 10, a title on Particular Rules Applying to War and other Extraordinary Situations - today's constitution considers two types of emergency situation: War and "extraordinary conditions" (Sjöholm 1974).

No serious attempts to define these situations were made. Even though it was stressed that the definition of war is of utter importance in order to understand the measures included in the chapter on emergency rule in the constitution (Prop 1973:90), not a word was spent in defining "extraordinary conditions" (utomordentliga förhållanden) in the debates that preceded the adoption of the current constitution 
(Petrén 1962; Sträng 1962): «It is not surprising that the preparatory work did not foresee the 70ies' terrorist attacks but it still suffers from lack of reflection on emergencies in times of peace» (Jermsten 1992, 87).

In general there is little or no mention of nödrätten in the jurisprudential debate and the eventuality of "internal threats" is simply not addressed. A commentator bluntly concluded that «the scarce material says (...) a lot on the stability of the Swedish society» (Johansson 1985, 38). As early as in the 50ies, Nils Herlitz lamented this lack of studies $(1955,152-181)$, and today the very term constitutional emergency rule still sounds unfamiliar to many, including legal scholars.

A recent bill now under discussion does not add any further situations or causes (Prop. 2009/10:80). It ultimately seems to fall under the authority of tradition in using dual nature-hermeneutics. However, in the recent discussions of what situations would qualify for constitutional emergency, some attempts have been made to debate the specificities of these situations. The commission on constitutional reform proposed that the section in the constitution be changed to include "war, risk of war and emergencies" (SOU 2008:125, 98). The recent bill moreover acknowledges that the "war" in question must be of such nature that it effectively threatens the integrity of the territory or the state's existence (Prop. 2009/10:80, 10.2), implying that chapter 13 cannot be activated for peacekeeping activities overseas. The armed forces also pushed for the inclusion of situations of "urgent needs" (trängande behov), but the proposal was not accepted. The travaux préparatoires insisted that there would be no need to develop specific rules for civil emergencies (see for instance SOU 2008:61) even though the absence of such provisions had been highlighted by scholars (Eklundh, Stjernquist 1994), as well as in official reports, especially following the 2004 tsunami in which many Swedes perished (see Katastrofkommissionen and the report Sverige och tsunamin SOU 2005:104).

In an effort to explain the longevity of the theory of the double origin of emergencies, we should remember the strict military legacy of many emergency-related institutions, such as the French état de siège, that could only be declared in event of invasion or armed insurgency, pursuant to art. 1 of the law of 1878. Originally at least, it was strictly limited in length and territorial range: The état de siège could only be declared on places de guerre (even though after 1797 it was extend- 


\section{SORTING OUT MODERN CONSTITUTIONAL...}

ed to all communes de l'intérieur and ended up, in August 1914, to be used to guarantee order on the entire territory of France during the general mobilization). This institution inspired the German imperial Kriegszustand regulated by art. IV § 197 of the 1849 Imperial Constitution that, in turn, modeled the state of war in the Statute of Prussia $\left(4^{\text {th }}\right.$ of June 1851). The common law equivalent is, unsurprisingly, martial law.

The over-simplified classification in internal and external threats has sometimes suggested adding further categories: Clinton Rossiter, in his classical study on Constitutional Dictatorship, for instance, held the distinction to be too reductive. His idea was to include a third category of emergencies: Economic depression (today we would probably also add recession). He was thinking about the crash on Wall Street and the following New Deal legislation, and hence concluded that economic emergencies require legislative measures and not merely executive decrees (Rossiter 1948, 6). More recently, the oversimplified vision of the nature of emergencies has been the object of criticism. Some have claimed that «the world's constitutions deal with all emergencies as if they were alike (...). But this "one size fits all" approach is a mistake (...). Future constitutions should be multi-track affairs that differentiate between types of emergencies» (Ackerman 2004, 1061).

There are, nonetheless, constitutions that discriminate on the basis of both the nature and degree of intensity of emergencies. The German Notstandsgesetze, the constitutional amendment approved on the $30^{\text {th }}$ of May 1968, distinguishes between state of defense (war), state of tension (rebellion) and state of calamity (natural disaster). The Spanish constitution from 1978 distinguishes too between estado de alerta, excepción and sitio (See Ley orgánica 4/1981). The Canadian Emergencies Act from 1988 also identifies three types of emergency for which different time periods are designated. The state of emergency can be declared for 30 days in the event of «threats to public order», for 90 days in the event of natural disaster, and 120 days in the event of war.

One problem with these distinctions is that the criteria of intensity, or degree of severity, coincides or overlaps with the nature of the threat, as if menaces of a certain nature or origin all had the same degree of intensity.

Anyway, even if some timid examples of distinction can be found, the prevailing attitude has been another. The example of the Philippines is emblematic: In a country regularly afflicted by natural disas- 
ters, the only form of emergency considered by its constitution is the State of rebellion.

To conclude, we should point to the fact that there are certainly unforeseeable events that not even the most far-sighted legislator can grasp, but much more often we deal with simply unforeseen and unexpected events that can - at least in principle - meet with much more detailed classification than just internal/external threats. I suggest that unforeseen events may be described as cases left unregulated by the legal system but that can be adequately grasped by applying the principle of analogy, such as a generalized web-based attack, for instance; whereas unexpected events might be foreseeable but occur suddenly, requiring prompt and immediate resolution, such as natural calamities.

\section{Who declares the emergency?}

The Roman dictator was nominated by the Consul in accordance with the Senate. ${ }^{4}$ This constitutes the paradigmatic case of hetero-investiture, i.e. the institution that declares the emergency is not the same as the one managing it. Attributing the authority of recognizing the emergency to a determinate body while attributing the responsibility of dealing with it to another, is a simple and rather efficient way to avoid that the body both declaring and managing the crisis has some "sinister interest" in doing so. This idea closely follows Rousseau's caveat in the $4^{\text {th }}$ book of Contrat Social: «le magistrat qui (...) fait taire [la loi] ne peut pas la faire parler.»

A contemporary example of hetero-investiture can be found in the Hungarian Constitution, which requires a parliamentary vote in favor of the emergency declaration by $2 / 3$ of the House before granting powers to the executive. A classic case is the French experience of the état de siège: In its original formulation, during the second republic (1848-1851), the state of siege was a form of «parliamentary dictatorship» to use the phrasing of Dufaure, the French minister of internal affairs in 1849. The state of siege could not be declared by the President unless Parliament ratified his decision within 48 hours (see art. 145 of the Constitution de l'An III [1795] and art. 66 of the Acte additionnel, $22^{\text {nd }}$ of April 1815). If the decision was not ratified, the state of siege was automatically abolished (Saint-Bonnet 2001). 


\section{SORTING OUT MODERN CONSTITUTIONAL...}

These precautions, however, were not observed by many of the countries that later adopted the French institution. Therefore, the state of siege evolved in a different direction, moving away from parliamentary-controlled mechanisms to more conventional executive power-controlled mechanisms. This legacy is particularly evident in the Latin-American experience of the state of siege. For instance, we should mention art. 23 of the Argentinean Constitution with such a provision: As recently stressed by Antonio María Hernandez, since 1930 the state of emergency has been declared more than 170 times; estado de sitio has been declared 52 times and has generally been used by the government in order to gain power at the expense of parliament (Loveman 1993; Negretto \& Rivera 2000, 1797-1824). We should also mention that similar provisions can be found in the constitutional regulations in Bolivia (artt. 111, 112), Brazil (artt. 136, 137), Colombia (artt. 212-215), Cuba (art. 67), Ecuador (artt. 180-182), El Salvador (art. 168), Guatemala (art. 139), Honduras (art. 187), Mexico (art. 29), Nicaragua (art. 185), Panama (art. 51), Paraguay (art. 288), Peru (artt. 137, 138), and Venezuela (artt. 337, 338).

If many Latin-American emergency experiences drifted away from the original model of hetero-investiture, they seldom represented an unequivocal counterexample, such as the self-activated emergency in art. 16 of the 1958 French Constitution: The President of the Republic both declares the state of emergency - «il en informe la nation par un message» - and acts as managing director of the crisis. It is true that, pursuant to art. 16, the President has to consult the Prime Minister, the Speakers of Parliament and Senate, as well as the conseil constitution$n e l$, but this procedure in itself does not represent an obstacle for the President's action.

Besides hetero-investiture, there are also other ways to establish an ex ante control on emergency declaration. For example, in art. 48 of the Weimar Constitution the emergency was chiefly the business of the executive (sometimes the emergency declaration came from the government and sometimes from the president), but the president had to sign the declaration into law and this requirement was designed to make sure the president and his cabinet agreed to the declaration. Therefore, in the eyes of contemporary legal scholars, there was an $e x$ ante constraint in the collegial responsibility required for declaring the state of emergency. Moreover, political responsibility was added to the collegial responsibility since the Reichstag could vote against the 
declaration of emergency. If the Parliament voted against the emergency declaration, however, it was not automatically annulled.

Again, the Swedish case is interesting because the constitutional emergency rule does not really provide for a declaration of emergency. Some legal experts unwarrantably assume that «there is no doubt when a situation is considered so extreme that a need to derogate from the ordinary constitutional order has arisen.» (Jermsten 1992, 17).

Pursuant to the constitutional provision in RF $13 \S 2$, nonetheless, a collegial responsibility is required when activating the procedures of the state of war. This mechanism also considers degrees of danger. In the event of (declared) war, the Foreign Affairs Commission (Utrikesnämndens ledamöter) institutes the so-called war delegation after consultation, if possible, with the Prime Minister. If the members of the Foreign Affairs Commission are hindered from performing the task, it can be executed by the Government. In the event that war is about to be declared (krigsfara), the war delegation can be instituted by the Foreign Affairs Commission in cooperation with the Prime Minister, as long as at least six members of the Commission agree. There has been some debate on the possibility for Sweden to declare war, and on whether war declaration is untimely in today's warfare. Interestingly, it has been stressed that a terrorist attack of a certain degree is to be considered an armed attack against which the country can legitimately use self-defense, following art. 51 of the UN Charter (Prop. 2005/06:111, 11), but an explicit reference to terrorism was rejected from the final recommendations of the Grundlagsutredning (SOU 2008:125, 516). These discussions are related to RF 10:9, according to which the government needs the agreement of parliament in order to declare war, except in the event of invasion.

In the event of an emergency that is not equivalent to a military invasion, it remains unclear what form a declaration could take. Pursuant to RF 7:3-4, however, decisions would be taken by the council of ministers (regeringssammanträde) in the presence of at least five members. In other words, notwithstanding the lack of regulation concerning the "declaration", there is strong evidence to suggest that decision-making would remain collective, thus effectively avoiding «minister rule».

We can therefore conclude that the ex ante control of the Swedish constitutional provisions on emergency first and foremost relies - in a way respectful of the democratic character of the fundamental law 


\section{SORTING OUT MODERN CONSTITUTIONAL...}

- on the collegial responsibility of the decision-makers. However, the recent commission on constitutional reform required the ex ante controls to be further strengthened by limiting the field of application of the rules in chapter 13 (with the specification sådant krig).

\section{What consequences derive from the declaration of emergency?}

Once a state of emergency has been declared, we subsequently need to look at what such a state entails. What consequences can be observed in a state of emergency? The general claim is that a state of emergency will invariably involve "government of a stronger character; that is the government will have more power and the people fewer rights» (Rossiter $1948,5)$. Such statements, however, suffer from a tremendously high level of generality.

A first step in narrowing down the issue is to ask three different types of questions:

(i) Who deals with the crisis? What powers are at the disposal of the body summoned to resolve the crisis? What responsibilities does it have? Does it enjoy immunities? What residual competences and powers can be used in order to exercise a form of ad interim control over the state of emergency?

(ii) What kind of rights can be subjected to derogation? On what basis?

(iii) What institutional changes are held to be legitimate? Under which conditions? And for how long?

There are links between these questions, but that does not hinder us from looking at each one separately.

\section{Who are the managers?}

Generally it is affirmed that the executive branch - usually in the form of head of state, president, prime minister and/or government - takes the lead during an emergency. It is also commonly assumed that this is "natural" since the measures are of an executive nature. Here, I will not develop the different variations on the theme. I shall only point to the fact that it is fully possible to have a legislative answer to a crisis. 
The numerous British emergency Acts, considered as temporary provisions $(1974,1976,1984,1989,1994,1998,2001,2004,2006)$ are designed for temporary emergency laws requiring a parliamentary vote. This is a paradigmatic example of what has been called the "legislative model" (Ferejohn \& Pasquino 2004, 210-238). This paradigm has developed significantly over the past decades, whereas the more traditional constitutional emergency rules are seldom used even by countries whose constitutions include such provisions, like France: Art. 16, in fact, has been used only once by De Gaulle. To settle emergency issues France refers to the law from April the $3^{\text {rd }} 1955$ (not abrogated through the 1958 constitution). Hence l'état d'urgence was recently imposed during the banlieues rioting at the end of 2005. Germany, Spain and Italy are also among the countries that have used legislative measures in dealing with terrorism for instance. The risk here is a spill-over effect due to the fact that the executive branch often justifies its actions on the basis of previous emergency acts that have not been overruled. To this evolution we should add that many emergency measures used today have an administrative character, e.g. FEMA (Dyzenhaus 2006, chap. 3).

Sweden is no exception to this trend. Many recent emergencyrelated issues have been triggered by discussions on the authority of the police under extraordinary circumstances: The types of emergency situation that are left out of chapter 13 in the constitution are linked to police work and regulated by Polislagen (SFS 1984:387). After the murder of Prime Minister Olof Palme in 1986, discussions on police authority under extraordinary circumstances were revived. Subsequently, the constitutional council has on different occasions expressed itself with regard to the action of the government in the reorganisation of the inquiry and contacts with the chief inquirer during the period 1986-87. In 1988-89 the question arose again with the Ebbe Carlsson affair, involving the secret service Säpo.

Even so, the Swedish constitution endeavors to attribute emergency powers without jeopardizing the principle of popular sovereignty. The main power-attributing norm concerns the war delegation of parliament, riksdagens krigsdelegation. Inspired by the 1920 Czechoslovakian constitution, upon the suggestion of the draft committee, it was turned into law with the reforms of 1964/65. It provides for the creation of a sort of ad interim house of representatives or a "miniparliament": A group of 50 members of parliament, proportionately 


\section{SORTING OUT MODERN CONSTITUTIONAL...}

selected among parties, headed by the speaker of the House, takes the place of parliament in the event of war (RF 13:2-3). If the war delegation is hindered from working properly, the government might substitute it (RF 13:5).

This provision was not designed as a form of delegation to the government or the majority party and it does not legitimate forms of monocratic rule by the prime minister or any other member of the cabinet. Rather it was designed for the (unlikely) event of military occupation. According to the official report on comparative constitutional law in SOU 2008:61, where the national case is set in its European context, Sweden is unique not in having war-related regulation as such, but in regulating specifically and in detail the conditions under occupation. In fact, the constitutional emergency provisions include very elaborate regulations in the event of occupation; a circumstance, however, that has not occurred in Sweden for centuries. Pursuant to RF 13:10-12, on occupied territory no election can be held and the Swedish parliament and government have no authority; public officials on occupied territory must «act in such a way that mostly favors the efforts of defense and resistance, the protection of civilians and other interests of Sweden». The purpose of these provisions is to guarantee that no occupying force can use the authority of Swedish officials for their own purposes. According to the final report of the commission on constitutional reform, there is no need to modify the provisions on occupation (SOU 2008:125, 512).

One of the key motives for adopting the article on war delegation was expressed by the minister of justice: «We currently lack specific rules in the event that Parliament, because of war, cannot perform its tasks. In the absence of any such rules, we would probably have to assume that his Majesty the King, in parallel with so-called constitutional emergency law, (nödrätt) will be invested with the competences of Parliament (...). For the democratic conception of society it is urgent to make sure that the competences of Parliament, even in such serious conditions as those we are concerned with, continues to be exercised for as long as possible by organs of popular representation.» (Prop. 1964:140, 170).

It has been stressed that this is «a Swedish codification of the Norwegian rules on the issue. The rules concerning (...) the possibility for government to substitute Parliament's authority were in principle designed with reference to the actions taken by Norway during the 


\section{PATRICIA MINDUS}

German invasion. Even if the invading power would presumably have been different after WW2, the situation was believed to evolve similarly and therefore an automatic enactment procedure, like the Elverumsfullmakt, ${ }^{5}$ was added to the Swedish constitution» (Jermsten 1992, 86).

\section{Are managers subject to control?}

As far as the techniques for controlling state power during emergencies are concerned, it has to be said that these are among the hardest ones to design. Many constitutional emergency rules simply do not provide for any such checks. This is the case of art. 16 in the current French Constitution: Parliament holds its session "de plein droit", but all legislative functions are excluded as well as every motion de censure on the emergency measures. This absence of ad interim checks was also the case of art. 48 of the Weimar Constitution: By reading art. 48 in the light of art. 25, the Reichspräsident had the power to systematically dissolve Parliament for three consecutive months (Grau 1932, 274-295; Watkins 1939, chapters 2 \& 3). This is how, at the beginning of 1924, «the Reichtag was in recess, and while the deputies were home, Germany was treated to one of the strongest doses of emergency legislation ever administered to any republic.» (Rossiter 1948, 48).

Some methods for avoiding such situations have been devised. The Roman dictator, for example, despite extensive powers, could neither declare war, nor rule in civil law suits, and he depended on the Senate for budget-issues (Mommsen 1887; Momigliano 1969, 27383). The exclusion of some areas of competence tends to be a subtle way to avoid over-concentration of power in the hands of the executive branch. But the complexity of foreseeing the areas of competence potentially involved in a specific action-class of emergencies usually suggested less sophisticated tools, such as prohibiting recess of Parliament; e.g. in the French état de siège, the President could not dissolve Parliament during an emergency.

The ad interim check that the Swedish constitution opted for is limiting the material fields of intervention: The war delegation, or the government in its place, cannot pass constitutional amendments during an emergency (RF 13:5), and cannot modify the order of parliament (Riksdagsordningen). According to RF 13:11, the head of state also 


\section{SORTING OUT MODERN CONSTITUTIONAL...}

follows the government or is otherwise considered hindered from performing his duties.

The archetypical check that can be exercised in the midst of an emergency is the power to abolish the state of emergency itself. This is the case, for instance, of the Polish constitution that provides for an absolute majority vote, with half of the members of parliament in the House, to invalidate the state of emergency, previously declared by the president upon the proposal of the council of ministers. No such rule exists in the Swedish case.

\section{What rights can be suspended?}

To exemplify the suspension of rights we can mention that in the classic form of état de siège, the rights that can be legitimately suspended, i.e. from which it becomes legal to derogate during the emergency, include guarantees against search without warrant, free movement (ousting non-residents), freedom of the press and freedom of assembly. However, historically, some rights were not subject to derogation, and this was the case of rights such as religious freedom and property.

Today, it has been argued that there are four basic human rights that are "non-derogable rights". According to the Venice commission, these include the right to life, the right not to be subjected to torture or inhumane treatment, the ban on slavery and the principle nulla poena sine lege (see European Commission for Democracy thought Law, a.k.a. the Venice Commission, that issued the report Emergency powers in 1995, available at http://www.venice.coe.int/docs/1995/ CDL-STD(1995)012-e.asp). Apart from including a basic principle (not a right), a problem with such minimalistic accounts is that they explicitly exclude rights and other protecting provisions that have a high likelihood of being carped and limited in a state of emergency, such as procedural guaranties against arbitrary arrest and procedures of due process that, in turn, hinge on clusters of basic principles that are not rights in themselves, such as no bis in idem.

Derogating from fundamental rights within the framework of constitutional government is a very tricky issue that I will not deal with here. The trickiness depends, first and foremost, on the "absolute" or "perfect" nature of some fundamental rights that do not intrinsically require balancing. This is the case of the right to physical integrity. The devil being in the details, we would need an undisputed theory of 
human rights if we were to enumerate here exactly what those rights are without falling into the trap of aforementioned minimalism. I shall not further dwell on this otherwise interesting topic: The literature on this point is virtually endless, as are cases of right-infringement. Suffice to say that, notwithstanding these difficulties, there seems to be some agreement on the fact that (some) fundamental rights are subject to lawful derogation. In fact, international law explicitly calls for derogatory measures in the realm of fundamental rights in the event of emergency (See art. $15 \S 1$ of the European Convention of Human Rights; art. 4 of the International Covenant on Civil and Political Rights; comments in Svensson-McCarthy 1998; De Schutter 2001).

From this perspective, it is important to stress that it is not clear in the Swedish case which rights would allow derogation in the event of emergency rule: After the 1974-76 reforms that added a list of fundamental rights to the constitution, the constitutional council concluded that it is possible to make exceptions to the material protection of these rights in such extraordinary situations. The extremely large discretion hereby implied has also been repeated by the doctrine: «From a practical point of view, the so-called enabling laws that enter into force if the country is at war naturally increase the competences of the State towards the citizens, but this provision belongs to administrative law and can therefore be excluded from consideration» (Jermsten 1992, 26; see also Heide 1998). Moreover, from a constitutional standpoint, the provision in RF 2:12 § 3 makes it clear that the cumbersome procedures normally required to pass liberty-restricting legislation need not be applied in the event of war.

In the absence of a settled doctrine, it is, in my view, still possible to make the theoretical claim that by highlighting what can be derogated we obtain a clearer picture of what cannot be subject to derogation. Therefore, my point is that to deepen these crucial aspects further, we should use this criterion to test the quality of emergency provisions. It is the nucleus of inviolable rights that is of importance if we want to grade emergency rules by their ability to protect us.

\section{Institutional changes}

As far as changes to the institutional settlement are concerned, it is clear that in most emergency rules stemming from military tradition, the major change to the institutional arrangement is the passing of 


\section{SORTING OUT MODERN CONSTITUTIONAL...}

power from the police to the armed forces. In the French état de siège, this implied the creation of military tribunals for "crimes against the Republic" and a significant transfer of power to military hands, but it did not imply the closing of civil tribunals (artt. 7 \& 11 of the 1849-law on state of siege). In the English and American tradition of martial law, conversely, the military power substitutes or replaces civil power (notwithstanding Ex parte Milligan). An emblematic formulation is that of the State of Washington, which provides for «the subordination of all civil authority to the military.»

In this respect, «the limit in Sweden between the tasks of the police and the armed forces is, internationally speaking, unusual. The police is entirely responsible for the internal security of the country, whilst the armed forces are responsible for protecting the country from external aggression» (Jermsten 1992, 44). Since five people were shot in Adalen by military troops called in as reinforcements by the police in a labor dispute in 1931, the armed forces cannot assist the police, except in offering transportation. No emergency situation should change this.

Overall, the risk is always that the crisis appears to be the occasion for instituting a new regime. Therefore time is a valuable parameter: If extended indefinitely, the state of emergency turns ipso facto into another regime. Among such examples, the case of Egypt is often mentioned in that it came under an emergency regime during the six-day war in 1967, a condition that was renewed after the murder of Sadat, with the "exception" (sic!) of 18 months in 1980. Among the notable cases of long-lasting emergency regimes we should mention Nepal, Brunei (since December 1962) and Swaziland (since April 1973). This aspect brings us to the next step in our taxonomy: Who declares the end of the emergency?

\section{Who declares the end of the emergency?}

In constitutional design, we find basically three possibilities as to who may declare the end of an emergency:

The first scenario is that the same monocratic institution unilaterally declares both the start and the end of the emergency. A similar form of self-activation can be found in the French Constitution from 1958, where the President enjoys such a power. This is a dubious way 
to resolve the issue that challenges the tradition of constitutionalism, since it ultimately depends on the judgment of a single person.

The second possibility is to preventively fix the length of the state of emergency. This is the classical remedy and paradigmatically the case of hetero-investitures where the prevailing method used for distinguishing between the activating/ deactivating body and the managing institution(s) is to predetermine the duration of the extraordinary condition. This technique was already used in Roman dictatorship with a fixed 6-month term that (until Hannibal) fitted the period in which Romans took up arms. In the French model of état de siège, the act (adopted by Parliament) declaring the state of siege also indicates its length (which was usually expressed in weeks or months, but in some cases lasted years). Today, fixing the term is the tool used in the constitution of Poland where the state of emergency can be declared for 90 days and extended once for another 60 days on approval of the Sejm, the most important of the parliamentary chambers. The problem with this technique is that it does not take into consideration the varying nature of the threat and thus amounts to a rather rigid system.

A third way to address the end of the emergency is to require a vote in Parliament. Even though it might be the same body that thus declares the beginning and the end of the crisis, as in the case of the British emergency acts after WW2, arbitrariness is limited because of the collegial structure of parliament. An example of this third type can be found in the German Grundgesetz: According to GG art. 1151(2), the state of emergency ends when the majority votes against it in both chambers. This latter mechanism has met with favor in some recent proposals. For instance, Bruce Ackerman in The Emergency Constitution from 2004 suggested the creation of a supermajoritarian escalator, where extension in time is proportional to the ever higher qualification of the majority: Here the executive branch unilaterally declares the state of emergency for a very brief period (one or two weeks). In order to extend it for another 2-3 months, $60 \%$ of Congress has to vote in favor; to extend it to 5 months, $70 \%$ would be required and finally $80 \%$ would be necessary for further extension. The idea is that «as the escalator moves to the eighty-percent level, everybody will recognize that it is unrealistic to expect this degree of legislative support for the indefinite future (...). The majority can no longer present itself as the country's savior, since the support of the minority is fundamental to an extraordinary regime» (Ackerman 2004, 1048). 


\section{SORTING OUT MODERN CONSTITUTIONAL...}

This solution relies on a high degree of democratic accountability, but it is not automatically respectful of constitutionalism: Suffice to say that a large majority of scared members of Parliament can ruthlessly extend a state of emergency way beyond what is necessary. The basic idea is that the higher the number of people involved in making the decision, the less likely an arbitrary extension becomes.

Compared to these often used solutions, Sweden has a slightly different settlement. To require a vote in Parliament would be meaningless in the event that a war has been declared and the war delegation or the government is in charge. However, it is undisputed that the authority of the war delegation would cease as soon as the parliament is able to perform its task (Holmberg 2006, 559). It has now been suggested that this requirement be stated explicitly in the constitution (Prop. 2009/10:80, 207). A sensible degree of discretion can, nonetheless, be detected in leaving to the mini-parliament the task of setting the time limit of its own existence. Moreover, there has been some discussion on whether the government is authorized to end the state of war in the place of the parliament or the war delegation and if this can only be done «to the defense of the country» or also under other conditions (SOU 2008:125, 516-520). But no decision has been reached in this regard.

\section{Concluding}

Once normalcy is re-established, it is time to draw some concluding remarks. This implies that we should address the problem of what we want to "save" when we call for salus rei publicae, the welfare of the State. This question can readily be reformulated: What is the purpose of the state of emergency? It is intrinsically linked to the aforementioned problem, namely "what rights can we derogate from and what institutional changes are justified in an emergency?" What we consider to lie beyond any possible derogation is specifically what we must not lose if we are to say that we re-established normalcy. This, in turn, sets the stake for assessing the quality of the emergency provisions. This implies that we need to ascertain the purpose or aim because we need to know if we have achieved it. In institutional terms, we should thus examine if there is a possibility to seek redress or to stigmatize inadequate action. In other words: Is there any judgment a posteriori 
on the actions undertaken? Can these actions be subjected to judicial or other review?

The general aim of all constitutional emergency governance is $s a$ lus rei publicae. One need not be a refined hermeneutic to realize that such an appeal can be stretched to fit just about anything. Perhaps, a more convincing argument is that of Machiavelli (Discorsi, XXXIV, 11): Emergency rules are derogatory rules whose principle of justification or ratio is to avoid late action (il moto tardo). At the end of the day, however, simply looking at formal declarations of intention is not very productive because they are too generic and often reflect wishful thinking.

Another, perhaps more promising option for establishing the ratio of the emergency provisions is to look at what the constitution considers to be binding even during an emergency. Emergency rules - their explicit formulation, location within the legal system, their scope and range, procedures and so forth - are interesting as far as they enable us to pinpoint what is considered to lie beyond derogation in a determinate context. By highlighting the sacred cow of each legal system, the purpose of the state of emergency can be determined. In fact, in order for a constitutional emergency not to turn into a revolution, a coup d'état, or other forms of so-called normative facts extra ordinem, it has to present a "conservative function" as opposed to evolutionary or progressive functions. In other words, a constitutional emergency must not have a spill-over effect on the constitution. This option of highlighting the inviolable, nonetheless, involves considerable complications since the ratio has to be established on a case-to-case basis.

Yet another option is to examine whether the constitutional arrangement provides for an ex post assessment of the actions undertaken by the legitimate authority during the crisis. This option is particularly interesting because of the possibility to eventually seek redress. As far as forms of ex post adjudication are concerned, comparative law has relatively little to suggest. Ex post adjudication is often discussed in legal theory and seems to be an option especially for common law countries. However, a few cases should be mentioned such as the French référé liberté and the Spanish and Latin-American amparo. We should stress that adjudication is generally attributed to the courts, but other institutions can play a similar role, like high administrative judges, parliamentary commissions, independent authorities, etc. 


\section{SORTING OUT MODERN CONSTITUTIONAL...}

Among the "classical institutions" of emergency there is no real ex post judgment of the actions undertaken by the authority summoned to "resolve" the crisis. For instance, in the French state of siege there is no judicial review of the emergency measures. The role played by the courts in interpreting art. 48 of the Weimar Constitution was also extremely limited (the control was supposed to be exercised by the Reichstag, usually in recess). The Reichsgericht expressed itself a few times, but the jurisprudence shows that the courts systematically held it to be the responsibility of the President or of the Parliament to verify that a certain measure was justified under art. 48, effectively preventing any review through interpretation (Friedrich 1928, 188).

Now, one might assume that the situation is different in legal contexts such as the American one, where judicial review is a cornerstone of the constitutional arrangement. Of course, the U.S. has a tradition of courts looking into the action of the Executive. The so-called Guantanamo cases have confirmed this in the public eye. However, the Youngstown-framework (from Youngstown Sheet $\mathcal{E}$ Tube Co v. Sawyer, 1952) which is still used to define the role of the judiciary in cases where martial law has suspended habeas corpus, shows that even here courts are deferential: According to the Youngstown-framework - emerging from Judge Jackson's concurrence - «the widest latitude of judicial interpretation» would be given in the event of «express or implied authorization from Congress», which basically invalidates judicial review; in the event of an executive order from the President in an area of concurring authority, the judiciary can only express itself on the part that is the authority of Congress (the President could bring only the executive's independent powers to bear, on which the emergency measure would stand or fall); only those presidential actions which are in direct contravention with the express or implied will of Congress are subject to scrutiny by the courts. So the «Court's deferential treatment of congressional-executive cooperation allows, if not invites, the immodest delegation of emergency powers» (Collins Weida 2004, 1409). In general, judicial review risks deferring treatment because of courts lagging behind, but some have also stressed the conservative tendencies in the common law tradition making significant constraint unlikely (Scheuerman 2008, 258-286).

Historically speaking, it is true that many common law systems have tried to avoid - because of the principle of stare decisis - ambiguous and embarrassing precedents and have overall preferred to avoid 
courts getting involved by leaving the responsibility to the political actors. The paramount example of an emergency regime with an $e x$ post adjudication mechanism based on political responsibility is the English Bill of Indemnity: With the rise of the cabinet system (Speech on Behalf of the Constitution against the Suspending and Dispensing Prerogative, 1776) this impunity act was grounded firmly on political responsibility. In order to avoid famine in the British Isles, the cabinet, violating the statutes on the free export of wheat and grain, invoked the royal prerogative of the «urgency of the necessity» and imposed a ban on export, leaving Parliament free to pass an Act of Indemnity in the aftermath. Such bills were used after wars, rebellions and other situations suspending habeas corpus. This idea of leaving the responsibility with the political actors, withdrawing it from the courts, has become fashionable again with Oren Gross' extra-legal measures model (Gross $2003 ; 2006 ; 2008)$. A problem with these solutions is that we cannot reason in irrefutable terms, iuris et de iure, on the emergency regime, since we cannot determine beforehand the nature of the crisis: i.e. if it derogates from a previous rule or if it abrogates it.

To conclude, we may stress that our inability to anticipate the exigencies of any particular emergency is often overstated. Emergency legislation can and is being drafted prospectively in anticipation of a broad range of emergencies. Several techniques and mechanisms with varying degrees of sophistication, compatibility with the rule of law, and effectiveness - have been elaborated by different countries. The legal and political scholar should analyze further such grey areas in order to elaborate constructive theses. Even if we acknowledge social, political and, generally speaking extra-legal pressures on the legal and constitutional settlement in an emergency, the managing body, which often amounts to the executive branch of government, can and ought to be held in check through legal means. There is still a lot of work to be done for those interested in refining the statutory and/or constitutional devices that can be designed for dealing with emergencies. We need to improve our skills in finding appropriate answers for emergencies and other unexpected situations according to their nature, intensity and occurrence within a determinate political and legal culture. 


\section{SORTING OUT MODERN CONSTITUTIONAL...}

\section{NOTES}

* This text is an extended and revised versionof a paper presented at the Ernst Cassirer Summer School, organized by the Swedish Collegium for Advanced Study in collaboration with the Helsinki Collegium for Advanced Studies, August 20-22, 2009. All translations are mine. I would like to thank the anonymous reviewers for their comments.

1. Some material can be found in official declarations, as for instance by the Swedish council of constitutional affairs (KU), but the doctrine is missing: An award-winning dissertation on this singular subject lamented «the conceptual confusion on the topic» (Jermsten 1992, 9). The situation in Norway is notably better, in particular due to the legal scholar Frede Castberg's two seminal works (1944 and 1953), as well as his Rett og revolusjon i Norge (1974).

2. See grundlagsutredningen. The recent bill from December 15th, 2009 (Prop. 2009/10:80) should also be mentioned, as well as the earlier proposal of the grundlagsutredningen (SOU 2008:125). A special expert group on constitutional crisis management (Krisberedskapen $i$ grundlagen) has also expressed an opinion: see SOU 2008:61.

3. Some other dispositions are also involved with emergency issues such as RF 9:3 (mobilization budget), RF 9:8 (right of government to use the state's resources) \& RF 10:9 § 1-2 (use of armed forces in warfare). Chapter 8 in the constitution on normative production, providing for urgent and necessary measures to be taken, is another rule that should be read on the background of "emergency rule" (cf. RF 8:6, 8:7, \& 8:10), as well as the provisions concerning simplified procedures of decision-making in military affairs (RF 7:3). Another important rule concerns the right of government to authorize the use of violence by the armed forces (RF 10:9 §3). Chapter 13 has been modified seven times to date, with some major changes in the bill (prop. 1987/88:6) following a report by the commission folkstyrelsekommittén (SOU 1986:28) that concerned elections on occupied territory. Today, it is again under scrutiny after the recent constitutional reform debates and the aforementioned bill of December $15^{\text {th }} 2009$.

4. The dictator was nominated by one consul in agreement with the other and with the Senate, at night, turned to the East on Roman territory, thus the formula "dictator: quod a consule dicebatur", the dictator is that what the consul says. See Nicolet 1982, 562-588; Nippel 2000, 5-23.

5. The Norwegian Parliament under German occupation prepared a decree (without a vote) conferring plenitudo potestatis to the government back in Oslo, while going into recess. On the $9^{\text {th }}$ of April 1940, the Parliament, Stortinget, met in Elverum, close to the Swedish border, while escaping the Nazis. The enactment, known as Elverumsfullmakten, was signed at this location. It states as follows: «Stortinget bemyndar Regjeringen til, inntil den tidspunkt kommer da Regjeringen og Stortingets presidentskap etter konferanse innkaller stortinget til neste ordinarie møte. Å vareta rikets interesser og treffe de avgørelser og beføyelser på stortingets og Regjeringens vegne, som må anses for påkrevd av hensyn til landets sikkerhet og framtid.» The Norwegian supreme court, Høyestrett, and the post-war commission confirmed the legitimacy of the enactment.

\section{REFERENCES}

Ackerman, Bruce 2004. Emergency Constitution. Yale Law Journal, 2004, vol. 113, 1029-1091

Benediktsson, Bjarni 1966. Konstitutionel nødret. Tidsskrift for Rettsvitenskap, 1966, 273-289. 


\section{PATRICIA MINDUS}

Blomkvist, Curt 1972. Rätten till självförsvar. Om tillåtet och otillåtet våld $i$ nödsituationer. Stockholm: Forum.

Bluntschli, Johann Kaspar 1857. Allgemeines Staatsrecht. München: Cotta Castberg, Frede 1944. Postliminium: en undersøkelse av rettsspørsmål i forbindelse med ophør av okkupasjon. Uppsala: Almqvist \& Wiksell.

Castberg, Frede 1953. Konstitusjonell nødrett. Utredning avgitt etter oppdrag av stortingets presidentskap, Dokument n. 2 (available at www. regjeringen.no).

Castberg, Frede 1974. Rett og revolusjon i Norge. Oslo: Universitetsforlaget. Collins Weida, Jason 2004. A Republic of Emergencies: Martial Law in American Jurisprudence. Connecticut Law Review, 2004: 36, 1397-1439.

De Schutter, Olivier 2001. La Convention européenne des droits de l'homme à l'épreuve de la lutte contre le terrorisme. Revue universelle des droits de l'homme, 13(5-8), 2001, 185-206.

Dyzenhaus, David 1997. Legality and Legitimacy: Carl Schmitt, Hans Kelsen and Hermann Heller in Weimar. Oxford: Clarendon.

Dyzenhaus, David 1998. (Ed.) Law as Politics: Carl Schmitt's Critique of Liberalism. London: Durham.

Dyzenhaus, David 2006. The Constitution of Law. Legality in a Time of Emergency, Cambridge: Cambridge University Press.

Eklundh, Claes \& Stjernquist, Nils 1994. Krissituationerna och regelverket. In Jonasson, Kjell et al., När krisen kommer, Stockholm: Kungl. Krigsvetenskapsakad 1994, 28.

Ferejohn, John \& Pasquino, Pasquale 2004. The Law of Exception: A Typology of Emergency Powers. In I.con, 2004, Vol. 2, Is. 2, 210-238.

Friedrich, Joachim 1928. The Issue of Judicial Review in Germany. Political Science Quarterly, XLIII, 1928, 188-200.

Grau, Richard 1932. Die Diktaturgewalt des Reichspräsidenten. In Gerhard Anschütz \& Richard Thoma (eds.) Handbuch des deutschen Staatsrechts. Tübingen: Mohr.

Gross, Oren 2003. Chaos and Rules: Should Responses to Violent Crisis Always Be Constitutional?. Yale Law Journal, 2003, Vol. 112, March, 1066-68 Gross, Oren 2006. What “Emergency" Regime?. Constellations, 13(1), March 2006, 74-88.

Gross, Oren 2008. Extra-legality and the Ethic of Political Responsibility. In V. Ramraj, Emergencies and the Limits of Legality. Cambridge: Cambridge University Press, 60-93.

Heide, Ola Rambjør 1998. Konstitusjonell nødrett: sett i lys av den europeiske menneskerettighetskonvensjon artikkel 15. Oslo: Tano Aschehoug Herlitz, Nils 1955. Svensk stats- och förvaltningsrättslig forskning under 50 år. In Festskrift utgiven av Stockholms Högskolas Stats- och Rättsvetenskapliga fakultet, Stockholm: Norstedt, 152-181.

Holmberg, Erik 2006. Grundlagarna: regeringsformen, successionsordningen, riksdagsordningen. Stockholm: Norstedts juridik. 


\section{SORTING OUT MODERN CONSTITUTIONAL...}

Jellinek, Georg 1887. Gesetz und Verordnung. Freiburg: Mohr. Jermsten, Henrik 1992. Konstitutionell nödrätt. Stockholm: Juridiska Fakulteten i Stockholm.

Johansson, Lars 1985. Konstitutionell nödrätt: en oskriven speciallag med obestämt innehåll, VT 1985 (dissertation manuscript, available at the Swedish Royal Library in Stockholm).

Kohler, Joseph 1915. Not kennt kein Gebot. Die Theorie des Notrechtes und die Ereignisse unserer Zeit. Berlin: Rothschild.

Lauta, Kristian Cedervall 2008. Egentlig nødret - et forfatningsretligt stadium. København: Jura (dissertation, available at the Danish Royal Library in Copenhagen).

Loveman, Brian 1993. The Constitution of Tyranny: Regimes of Exception in Spanish America. Pittsburgh: Pittsburgh University Press.

Momigliano, Arnaldo 1969. Ricerche sulle magistrature romane. In Arnaldo Momigliano (ed.), Quarto contributo alla storia degli studi classici e del mondo antico. Roma: Edizioni di storia e letteratura, 273-83.

Mommsen, Theodor 1887. Römisches Staatsrecht. Leipzig: Sonderausgabe der Wissenschaftlischen Buchgemeinschaft.

Negretto, Gabriel L. \& Rivera, José Antonio Aguilar 2000. Liberalism and Emergency Powers in Latin America: Reflections on Carl Schmitt and the Theory of Constitutional Dictatorship. In Cardozo Law Review, 2000: 21, 17971824.

Nicolet, Claude 1982. La dictature à Rome. In M. Duverger (ed.), Dictatures et légitimité, Paris: Puf, 567-588.

Nippel, Wilfred 2000. Emergency Powers in the Roman Republic. In Bernard Manin (ed.), La théorie politico-constitutionnelle du gouvernement d'exception, Paris: Crea, 5-23.

Petrén, Gustaf 1962. När får grundlagarna åsidosättas?. Svensk Juristtidning, 1962, 486-488.

Ramraj, Victor 2008. (Ed.) Emergencies and the Limits of Legality. Cambridge: Cambridge University Press.

Rossiter, Clinton 1948. Constitutional Dictatorship: Crisis Government in the Modern Democracies. Princeton: Princeton University Press.

Saint-Bonnet, François 2001. L'Etat d'exception. Paris: Puf

Scheuerman, William 2008. Presidentialism and Emergency Government. In V. Ramraj (ed.), Emergencies and the Limits of Legality, Cambridge: Cambridge University Press 2008, 258-286.

Sjöholm, Elsa 1974. Den statliga nödrätten och dess problematik. Svensk Juristtidning, 1974, 579-591

Sträng, Gunnar 1962. Genmäle. Svensk Juristtidning, 1962, 488-489

Svensson-McCarthy, Anna Lena 1998. The International Law of Human Rights and States of Exception with Special Reference to the Travaux préparatoires and Case-law of the International Monitoring Organs. Den Haag: M. Nijhoff

Watkins, Frederick 1939. The Failure of Constitutional Emergency Powers under the German Republic. Cambridge, Mass.: Harvard University Press. 